\title{
Metastatic well differentiated squamous cell carcinoma in the prepuce of a dog: a report of clinicopathological, immunophenotypic and therapeutic approach
}

\author{
[Carcinoma de células escamosas bem diferenciado metastático no prepúcio de cão: relato da abordagem \\ clinicopatológica, imunofenotípica e terapêutica] \\ P.A. Auler ${ }^{1}$, C.O. Gamba ${ }^{1}$, R.S. Horta ${ }^{2}$, G.E. Lavalle $^{2}$, G.D. Cassali ${ }^{1^{*}}$ \\ ${ }^{1}$ Instituto de Ciências Biológicas - Universidade Federal de Minas Gerais - ICB-UFMG - Belo Horizonte, MG \\ ${ }^{2}$ Escola de Veterinária - Universidade Federal de Minas Gerais - EV-UFMG - Belo Horizonte, MG
}

\begin{abstract}
This report describes a case of a well differentiated squamous cell carcinoma (SCC) of the foreskin of a dog, with metastasis in the regional lymph node. A six-year-old male intact Pit Bull dog presented a preputial ulcerated lesion with an evolution time of one year and enlarged left inguinal lymph node. Surgical resection of the preputial lesion and inguinal lymph nodes was made. The diagnosis of a well differentiated SCC was made following histopathological analysis and immunohistochemistry technique was used to confirm lymph node metastasis and to determine the histological features of the tumor. Here we demonstrated that immunohistochemistry can be an important complementary diagnostic tool to assess the prognostic features of SCC and to determine the treatment of choice. Also, the combination of COX-2 selective inhibitors in adjuvant therapy is presented as an effective alternative treatment for metastatic SCC in dogs.
\end{abstract}

Keywords: metastasis, tumor, skin, immunohistochemistry, chemotherapy

\section{RESUMO}

Este relato descreve um caso de carcinoma de células escamosas (CCE) bem diferenciado no prepúcio de um cão, que apresentou metástase para o linfonodo regional. Um cão macho inteiro, de seis anos de idade, da raça Pit Bull, apresentou lesão ulcerada na região prepucial, com evolução de um ano, $e$ linfonodo inguinal esquerdo aumentado, e foi submetido à exérese cirúrgica. O diagnóstico de CCE bem diferenciado foi obtido após avaliação histopatológica, e a técnica de imuno-histoquímica foi realizada para confirmação de metástase em linfonodo e para determinação das características imunofenotípicas do tumor. No estádio avançado da doença (T3N2MO) e com positividade para COX-2, foi proposta a utilização de quimioterapia adjuvante com carboplatina combinada com inibidor seletivo de COX-2. Neste estudo, demonstrou-se que a técnica de imuno-histoquímica pode ser uma importante ferramenta diagnóstica para determinar o prognóstico e o tratamento de escolha do CCE. Adicionalmente, a associação de carboplatina com inibidores seletivos de COX-2 é apresentada como uma efetiva alternativa de tratamento de CCE metastáticos caninos.

Palavras-chave: metástase, tumor, pele, imuno-histoquímica, quimioterapia

\section{INTRODUCTION}

Squamous cell carcinoma (SCC) is an epithelial origin neoplasm frequently observed in the skin of dogs and represents about $5 \%$ of cutaneous tumors in this species (Gross et al., 2005;

Recebido em 9 de abril de 2013

Aceito em 25 de junho de 2014

*Autor para correspondência (corresponding author)

E-mail: cassaliig@icb.ufmg.br
Withrow and Vail, 2007). It can be extremely invasive and destructive with gradual loss of cutaneous tissue; however metastases are rarely observed and occur only in late disease. The regional lymph nodes and the lung are the most common sites for metastasis development (Gross et al., 2005; Withrow and Vail, 2007) 
Regardless of tumor location, SCCs can be classified into different grades of differentiation: well differentiated, moderately differentiated and poorly differentiated (Gross et al., 2005). Differences in clinical and histopathological features may be observed among them. The well differentiated subtype is the most commonly observed in canine species, which is characterized by masses or cords of neoplastic epithelial cells that proliferate and invade the dermis and subcutis. The hallmark of this subtype is the presence of keratin pearls in varying numbers and size, which are composed by concentric layers of squamous cells with gradual increase of keratinization toward the center (Gross et al., 2005).

Currently, little is known about the clinicopathological and immunophenotypical behavioral of canine SCC. Most data available in the literature is related to human SCC. However, despite the great importance of these studies for Veterinary Medicine, it has become clear that there is a need for specific knowledge that may be helpful in determining the diagnosis, prognosis and the clinical practice. Therefore, the goal of this study is to report a case of SCC in the foreskin of a dog presenting metastasis to the regional lymph node. Here we emphasize the histopathological and immunophenotypic features of the tumor and the clinical and therapeutic approaches.

\section{CASE REPORT}

A six-year-old male intact Pit Bull dog presented a preputial ulcerated lesion with an evolution time of one year, besides progressive weight loss and reduced appetite. On the clinical examination the dog was underweight with a score of three in a previously validated 9-point body condition scoring system (Muller et al., 2008), normal breathing pattern, heart rate of 130 beats per minute and a rectal temperature of $39.3^{\circ} \mathrm{C}$.

The lesion had an average measured size of $10 \mathrm{~cm}$ in diameter, presenting necrosis and ulceration areas with purulent and bloody-stained exudates. The mass was adhered to the skin preventing penile exposure. Also, the left inguinal lymph node was enlarged. No foci of distant metastasis were observed on abdominal ultrasound and thoracic radiographs (laterolateral and ventro-dorsal).

Considering the lesion size and the severity of clinical presentation, tumoral exeresis was performed with wide surgical margins (Withrow and Vail, 2007). Due to serious penis exposure after extensive removal of the prepuce and to achieve wide surgical margins, the procedure also included penile amputation, orchiectomy and urethrostomy in the scrotal region and bilateral inguinal lymph nodes removal to search for metastases. The penis and the prepuce with the tumoral mass and inguinal lymph nodes were sent to Laboratory of Comparative Pathology ICB/UFMG for histopathological diagnosis.

The macroscopic analysis showed a well circumscribed mass of about $15 \mathrm{~cm}$ in diameter and firm in consistency, located in the preputial sheath. The cut surface presented a creaking sound and a homogeneous aspect with white color. The left inguinal lymph node was enlarged presenting irregular external surface, altered consistency and unchanged cut surface. The right inguinal lymph node didn't reveal visible changes, however, small areas of approximately $0.2 \mathrm{~cm}$, with altered consistency and white in color were observed on the cut surface. Tumor specimens were collected, fixed in $10 \%$ neutral buffered formalin solution and embedded in paraffin. Afterwards, $4 \mu \mathrm{m}$ histological sections were obtained from these fragments and stained with the Hematoxylin and Eosin technique.

Histological analysis revealed expansive tumor mass lined by ulcerated skin presenting proliferation of polyhedral epithelial cells in nest or cord arrangements and surrounded by abundant connective tissue. The neoplastic cells showed abundant eosinophilic cytoplasm and multiple nucleoli. Central accumulations of compact laminated keratin (keratin pearls) were observed in the epithelial cell clusters (Figure 1a). Mitotic index was 2.5 mitoses/field (40x magnification). The right inguinal lymph node revealed metastatic nests of polyhedral cells with abundant eosinophilic cytoplasm, pleomorphic nuclei and prominent nucleoli. In addition, reactive hyperplasia and focal necrosis were observed. In the left inguinal lymph node only reactive hyperplasia could be seen. 
In order to better characterize the tumor, immunohistochemical technique was done in sections of neoplastic tissue. A peroxidase system was used with identification of the secondary antibody by the polymer (Advance HRP enzyme, DakoCytomation, Carpinteria, California, USA). Antigen retrieval was performed in a water bath at $98^{\circ} \mathrm{C}$ with a citrate buffer solution at pH 6.0 (DakoCytomation, Carpinteria, California, USA). In order to block the endogenous peroxidase activity, slides were incubated with a solution of $\mathrm{H}_{2} \mathrm{O}_{2}(3 \%)$ in methyl alcohol. Reagents were manually applied for 16 hours of incubation of the primary antibody and $30 \mathrm{~min}$ for the other reagents, except for diaminobenzidine chromogen, incubated for five min. The primary antibodies used for this technique were cytokeratin (1:100, AE1/AE3, Dako), E-cadherin (1:100, 4A2C7, Invitrogen), EGFR (1:100, 31G7, Zymed), HER-2 (1:100, cerbB2, Dako), Ki67 (1:25, Mib-1, Dako) and COX-2 (1:80, SP21, Neomarkers).

The immunostaining for HER-2 and EGFR was scored as follows: 0 no labeling; (+) faint, incomplete membranous pattern; $(++)$ moderate, complete membranous pattern in less than $30 \%$ of the cells; $(+++)$ intense, strong membranous pattern in at least $30 \%$ of cells. The scores 0 and $(+)$ were considered negative; $(++)$ equivocal; and $(+++)$ positive. The immunostaining for Ecadherin was evaluated semi-quantitatively and scored with a five-category scale: negative (-), $<5 \%$ stained cells; positive (+), from $5 \%$ to $25 \%$ stained cells; positive (++), from $25 \%$ to $50 \%$ stained cells; positive (+++), from 50 to $75 \%$ stained cells; diffuse positivity $(++++),>75 \%$ stained cells. Immunostaining for COX-2 was evaluated to predict a specific complementary treatment to conventional chemotherapy. COX-2 expression evaluation was semi-quantitative and the distribution score defined by the estimated percentage of positive cells in 5 fields at $400 \mathrm{x}$ magnification: zero = absence; $1=$ fewer than $10 \%$ stained cells; $2=$ between $10 \%$ and $30 \% ; 3$ $=$ between $31 \%$ and $60 \% ; 4=$ more than $61 \%$ stained cells. For staining intensity, values from 0 to 3 were attributed: $0=$ absence, $1=$ weak staining, $2=$ moderate staining and $3=$ strong staining. The distribution score and the staining intensity were multiplied to obtain a total score, which ranged from 0 to 12 (Lavalle et al., 2009).
Cytokeratin AE1 AE3 expression was evaluated to confirm the epithelial origin of neoplastic cells within the tumor, the presence of metastatic epithelial cells in right inguinal lymph node and to search for micrometastasis in the left inguinal lymph node. The proliferative index was calculated by counting the number of $\mathrm{Ki}-67$ (anti-MIB-1) positively labelled nuclei in a total of 1000 neoplastic cells.

Immunohistochemical analysis revealed cytoplasmic staining for cytokeratin AE1AE3 in neoplastic cells in the tumor mass and right inguinal lymph node (Figure 1b). However, no labeling was observed in the left inguinal lymph node. E-cadherin expression was presented in $30 \%$ of the neoplastic epithelial cells. Interestingly, the central area of the epithelial cell nests showed an intense staining, whereas loss of membranous expression towards the periphery was observed (Figure 1c). Intense complete membranous staining for EGFR and HER-2 was observed at least in $30 \%$ of neoplastic cells (+++) (Figure 1d, f), whereas moderate COX-2 expression (score six) was seen in $35 \%$ of the neoplastic cells. Cellular proliferation index was 30\% (Figure 1e).

According to our clinical observations and based on the criteria of the TNM system, we could classify the patient as having an advanced stage disease (T3N2M0) (Withrow and Vail, 2007). Therefore, adjuvant chemotherapy with four sessions of carboplatin (B-Platin $®$, Carboplatin, Blausiegel, Brazil) intravenously at a dose of $300 \mathrm{mg} / \mathrm{m}^{2}$ every three weeks was proposed. Chemotherapy started immediately after wound healing. In each session the patient was premedicated subcutaneously with $2 \mathrm{mg} / \mathrm{kg}$ of ranitidine (Cloridrato de ranitidina, Farmace, Brazil) and $0.5 \mathrm{mg} / \mathrm{kg}$ of metoclopramide (Noprosil®, Metoclopramide, Isofarma, Brazil). The animal was treated orally with $1 \mathrm{mg} / \mathrm{kg}$ omeprazole.

Omeprazole (Quím. Intercontinental Farm., Brazil) was given daily for four days after each session. The blood cell count was monitored during 10 days after each chemotherapy session. The patient presented no side effects that would imply discontinuation of treatment. 


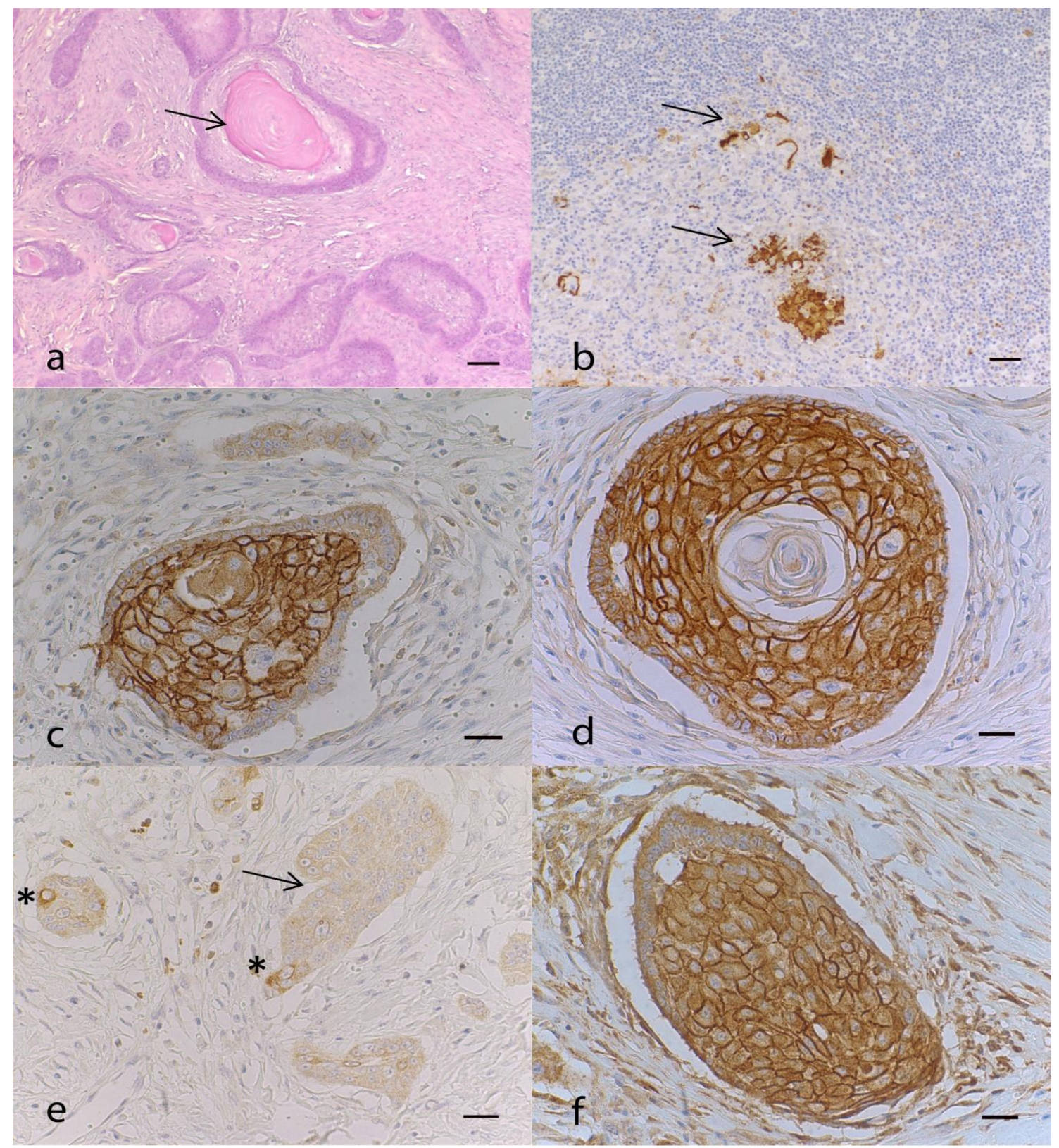

Figure 1. Photomicrographs illustrating the histological and immunohistochemical features of a canine skin squamous cell carcinoma: (a) Clusters of neoplastic epithelial cells showing central accumulations of compact laminated keratin (keratin pearls) (arrow). HE stain, scale bar, $100 \mu \mathrm{m}$; (b) Lymph node presenting neoplastic epithelial cells stained for CKAE1AE3 (arrow). Streptavidin-biotin-peroxidase anti-CKAE1AE3, counterstained with Harris's haematoxylin, scale bar, $50 \mu \mathrm{m}$; (c) Intense staining for E-cadherin in neoplastic epithelial cells mainly in the central area with loss of membranous expression towards the peripheral area of the nest. Streptavidin-biotin-peroxidase anti-e-cadherin, counterstained with Harris's haematoxylin, scale bar, $30 \mu \mathrm{m}$; (d) Neoplastic epithelial cells revealing intense complete membranous staining for EGFR (+++). Streptavidin-biotin-peroxidase anti-EGFR, counterstained with Harris's haematoxylin, scale bar, $30 \mu \mathrm{m}$; (e) Neoplastic epithelial cells with moderate intensity of staining for COX-2 (arrow). Areas of intense staining for COX-2 were observed (asterisk). Streptavidin-biotin-peroxidase anti-COX-2,

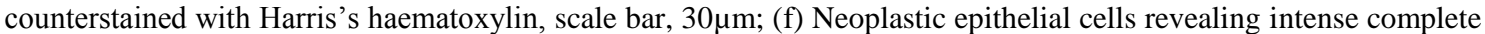
membranous staining for HER-2 (+++). Streptavidin-biotin-peroxidase anti-HER-2, counterstained with Harris's haematoxylin, scale bar, $30 \mu \mathrm{m}$. 
To achieve prolonged disease-free survival, the treatment with a selective COX-2 inhibitor was chosen based on immunohistochemical staining for COX-2 (Lavalle et al., 2012). Firocoxib was administered orally at a dose of $5 \mathrm{mg} / \mathrm{kg}$ every 24 hours for six months.

The patient was periodically monitored by complete clinical examination, abdominal ultrasound, chest radiography (latero-lateral and ventro-dorsal). Laboratorial exams included complete blood count and biochemical measurements of alanine transaminase, albumin, amylase, alkaline phosphatase, aspartate transaminase, calcium, cholesterol, creatinine, gamma-glutamyl transferase, phosphorus, total bilirubin, total globulin and urea. Currently the patient is healthy and the disease-free interval is greater than two years.

\section{DISCUSSION}

Squamous cell carcinoma is among the most prevalent malignant skin tumors in dogs (Withrow and Vail, 2007). However, despite its high frequency, few studies on the occurrence and treatment of SCC in dogs have been developed until now.

In the present study, the presence of keratin pearls and the reduced cellular pleomorphism in the tumor mass were compatible with the description of well-differentiated SCC subtype in human and canine species (Gross et al., 2005; Yanofsky et al., 2011). The epithelial origin of the neoplastic cells as well as the presence of lymph node metastasis observed in HE technique were confirmed through cytokeratin AE1AE3 expression on tumor cell nests and right inguinal lymph node.

Despite the well-differentiated feature, metastasis to lymph node could be explained by EGFR and HER-2 overexpression and the elevated cellular proliferation as evidenced by MIB-1expression in more than $30 \%$ of tumor cells. In humans, the overexpression of EGFR and HER-2 in SCC has been associated with increased metastatic potential and reduced overall survival. It has been linked to the activation of signaling pathways related to cellular proliferation, tumor invasion, migration and angiogenesis (O-charoenrat et al., 2002; Wolf-Yadlin et al., 2006). Tumor aggressiveness, defined by its metastatic potential, could also be associated with the gradual loss of E-cadherin expression toward the periphery of the neoplastic cell nests. These kinds of changes in cell adhesion molecules promote the rupture of cell-cell adhesion complex and the migration of malignant cells from the primary tumor. In humans, loss of Ecadherin expression has also been associated with distant lymph node metastasis (Nijkamp et al., 2011).

The use of systemic chemotherapy after surgery as an adjuvant treatment aimed to increase the overall survival and disease-free interval. According to Withrow and Vail, 2007, it should be encouraged for advanced stage patients. Satisfactory results were already obtained with cisplatin in dogs with metastatic squamous cell carcinoma (Himsel et al., 1986). Carboplatin is a second generation antineoplastic drug derivative of platinum that has fewer side effects than cisplatin (Rodaski et al., 2009). It is considered a cell cycle phase-non-specific drug that causes irreversible inhibition of protein synthesis due to covalent DNA-binding. As observed in the literature, chemotherapy was well tolerated and the patient showed no significant side-effects.

COX-2 expression is a potential predictive factor due to the possible association of COX-2 selective inhibitors, such as firocoxib, in adjuvant therapies (Lavalle et al., 2009), as performed in this case. According to Lavalle et al., 2012, COX-2 selective inhibitors provide therapeutic benefits to patients with tumors that present high COX-2 scores (6-12). In this report, treatment with firocoxib was based on the COX2 immunohistochemical expression score of six and provided a higher disease-free interval. The mechanisms by which COX-2 inhibitors exert antitumor function have not been fully elucidated but involve inhibition of cell cycle progression, angiogenesis and tumor growth and induction of apoptosis (Grösch et al., 2006).

In the present study we have described a tumor with histological well differentiated characteristics; however, with an aggressive morphology and high metastatic potential. This histological pattern was characterized by high expression of EGFR, HER-2 and COX-2, elevated mitotic index and loss of E-cadherin expression. We have also shown that due to the 
diversity of histologic subtypes and lack of clinicopathological studies of SCC in dogs, immunohistochemistry becomes an important complementary diagnostic tool to assess the prognostic features through molecular indicators and to determine the treatment of choice. Certainly, further large sample studies on the expression of these markers in SCC different subtypes may provide an efficient diagnostic and prognostic evaluation of these tumors in dogs. Furthermore, treatment with carboplatin offered good quality of life for the patient and adequate control of disease in the advanced stage. We demonstrated that adjuvant chemotherapy is an important alternative for the treatment of metastatic SCC in dog. Besides that, the combination of COX-2 selective inhibitors in adjuvant therapy for high $\mathrm{COX}-2$ grade tumors represents a potential target that must be considered in Veterinary Medicine.

\section{REFERENCES}

GRÖSCH, S.; MAIER, T.J.; THERTEN, J.M. et al. Cyclooxygenase-2 (COX-2) - Independent Anticarcinogenic Effects of Selective COX-2 Inhibitors. J. Nat. Cancer Inst., v.98, p.736-747, 2006.

GROSS, T.L.; IHRKE, P.J.; WALDER, E.J.; AFFOLTER, V.K. (Ed). Epidermal tumors. In: Skin diseases of the dog and cat. Clinical and histopathologic diagnosis. Oxford: Blackwell Science Ltd, 2005. p.932.

HIMSEL, C.A.; RICHARDSON, R.C.; CRAIG, J.A Cisplatin chemotherapy for metastatic squamous cell carcinoma in two dogs. J. Am. Vet. Med. Assoc., v.189, p.1575-1578, 1986.
LAVALLE, G.E.; BERTAGNOLLI, A.C.; TAVARES, W.L.F.; CASSALI, G.D. Cox-2 Expression in Canine Mammary Carcinomas: Correlation with Angiogenesis and Overall Survival. Vet. Pathol., v.6, p.1275-1280, 2009.

LAVALLE, G.E.; CAMPOS, C.B.; BERTAGNOLLI, A.C.; CASSALI, G.D. Canine Malignant Mammary Gland Neoplasms with Advanced Clinical Staging Treated with Carboplatin and Cyclooxygenase Inhibitors. In Vivo, v.26, p.375-379, 2012.

MULLER, D.C.M.; SCHOSSLER, J.E.; PINHEIRO, M. Adaptação do índice de massa corporal humano para cães. Cienc. Rural, v.38, p.1038-1043, 2008.

NIJKAMP, M.M.; SPAN, P.N.; HOOGSTEEN, I.L. et al. Expression of E-cadherin and vimentin correlates with metastasis formation in head and neck squamous cell carcinoma patients. Radiother. Onc., v.99, p.344348, 2011

O-CHAROENRAT, P.; RHYS-EVANS, P.H.; MODJTAHEDI, H.; ECCLES, S.A. The role of cerbB receptors and ligands in head and neck squamous cell carcinoma. Oral Oncol., v.38, p.627-640, 2002.

RODASKI, S.; DE NARDI, A.B.; PIEKARZ, C.H. Quimioterapia antineoplásica. In: DALECK, C.R.; DE NARDI, A.B.; RODASKI, S. (Ed). Oncologia em cães e gatos. São Paulo: ROCA, 2009. p.162-177.

WITHROW, S.J.; VAIL, D.M. (Ed). Withrow \& MacEwen's Small Animal Clinical Oncology. 4. ed. Philadelfia: Saunders Company, 2007. 846p.

WOLF-YADLIN, A.; KUMAR, N.; ZHANG, Y. et al. Effects of HER2 overexpression on cell signaling networks governing proliferation and migration. $\mathrm{Mol}$. Sys. Biol. v.2, p. 54, 2006.

YANOFSKY, V.R.; MERCER, S.E.; PHELPS, R.G. Histopathological Variants of Cutaneous Squamous Cell Carcinoma: A Review. J. Skin Cancer, v.2011, p.1-13, 2011. 